\title{
Employability Factors of Business Graduates in Kuwait: Evidence from An Emerging Country
}

\author{
Abdullah AL-Mutairi ${ }^{1}$, Kamal Naser ${ }^{2} \&$ Muna Saeid $^{1}$ \\ ${ }^{1}$ Arab Open University-Kuwait Branch, Kuwait \\ ${ }^{2}$ Financial and Economic, Kuwait \\ Correspondence: Abdullah AL-Mutairi, Department of Business Administration, Arab Open University-Kuwait \\ Branch, Kuwait. E-mail: almutairi@aou.edu.kw \\ Received: July 16, 2014 \\ doi:10.5539/ijbm.v9n10p49 \\ Accepted: August 4, 2014 \\ Online Published: September 25, 2014
}

\begin{abstract}
This study is set out to explore factors considered by employers when recruiting business graduates in Kuwait. Four categories of employability factors were used in the current study covering graduates knowledge, soft skills, personal abilities and working with groups. A questionnaire that contained these factors was distributed to Kuwaiti employers and the participants were asked to express the level of importance they assign to each of these categories. The results of the analysis revealed that participants attach a highest level of importance to graduates knowledge, soft skills and ability to work within groups. The participants attach low level of importance to the personal abilities of the graduates. The study concludes that employability factors are affected by employers' background characteristics, the firm's nature, size and ownership (whether family, public or government). Needless to say, in a country like Kuwait, employability factors are governed by cultural and social considerations.
\end{abstract}

Keywords: employers' perceptions, business graduates, education, employability, skills, Kuwait

\section{Introduction}

The relationship between quality of skills possessed by university graduates and the job market has been the focus of growing theoretical and empirical investigations in the education literature. The central issue in this literature is to examine employers' perceptions about the quality of university graduates in terms of their hard skills as and soft skills. Empirical studies offer inconclusive evidence but revealed that employers place great emphasis on graduates' soft skills, and their ability to deal empathetically and effectively with job's demands. It is widely known that hard skills are necessary to get a job but often insufficient to keep it. Soft skills assist graduates in progressing and maintaining their jobs. However, it is argued that universities together with educational authorities usually work together to adopt strategies that tackle skills deficits and match universities inputs with employers and businesses demand. Yet, some employers are not fully satisfied with the quality of university graduates. Hence, academics and educational authorities need to work closely with employers to ensure that university graduates possess skills that satisfy the market's needs. It is, therefore, of paramount importance to explore the main factors that employers expect business graduates to possess to enhance their employability chances.

The purpose of this study is to identify factors that employers expect business graduates in Kuwait to possess in order to secure jobs. The outcome of this study will assist policy makers at the country level together with policy makers at the university level in formulating their education strategies in a way that assists in satisfying the market demand. This is expected to increase graduates employability, reduce unemployment and stimulate economic and social growth.

Thus, the current study would be appreciated by students, academic institutions, researchers and employers. For students, it would help them in selecting universities that respond to employers' needs. For educational institutions, it might assist them in reshaping their curricula and teaching process and enhancing professional competencies of their lecturers to match the job-market conditions. It would also assist them in launching faculty development programs to ensure that they can prepare their students for job market. For researchers, it might motivate academic research and career development to look into new creative university teaching trends that 
help in acquiring career development skills. For employers, it would give them the opportunity to identify areas of business graduates weaknesses to arrange necessary training programs to tackle these weaknesses. In addition, the findings of this paper are expected to add a new dimension to the literature and contribute to the limited body of empirical studies about employers' perceptions towards the quality of university graduates in the Gulf Cooperation Council (GCC) region.

The rest of the paper is organized as follows: The next section provides a review to previous related studies. A brief description of the study methodology is offered in section 3 . While the findings are discussed in section 4 , conclusion, limitations and directions for future research are covered in the last section.

\section{Previous Related Studies}

Employability is a set of achievements, skills and personal attributes that help graduates to obtain employment and remain successful in their occupations (Yorke, 2006). According to Lowden et al. (2011), employers assume graduates to have skills and personal attributes such as: team-work, communication, leadership, critical thinking, problem solving and managerial abilities. A graduate job is not guaranteed unless skills and personal attributes possessed by the graduate are successfully used in the job (McCabe, 2010). In this respect, it important to point out that employer's requirements for graduates' employability varies according to the economic sector and across countries. Weligamage (2009) found that employer expectation and requirement differ according to different countries. He suggested that the needs of the employers and skills of learners should be taken into account in formulating future skills assessments. He recommended that universities should identify skill sets that will best serve the future labor market and align programs to meet those needs.

The employers' views of how well university graduates are prepared for the workplace have received widespread attention in the education literature and continued to be a commonly debated theme. Most of these researches have been conducted in various places. The following section offers a brief review of these studies.

Graham (2001) examined knowledge, skills, and abilities desired of employers of entry-level graduates of the Department of Agricultural and Extension Education. He found that graduates need to demonstrate the ability to work in groups, show leadership, dedication, and initiation more than they are now doing. He also found that employers viewed verbal expression, presentation skills, listening, and understanding instructions as being very important. Robinson and Garton (2008) used the Borich (1980) assessment model to identify skills most in need to enhance the curriculum in the College of Agriculture, Food and Natural Resources at the University of Missouri. They found that solving problems, communicating effectively, working on a team, thinking critically, and possessing interpersonal skills are the most important employability skills desired by employers. Robinson and Garton suggested that the faculty should arrange workshops/trainings programs to assist other faculty members in incorporating strategies for addressing deficiencies in the learning outcomes of their courses. Alston et al. (2009) examined the perceptions of employers of Land-Grant College graduates regarding their preparation for entry-level positions in the agricultural sector. They found that Land Grant University graduates are prepared in the areas of interpersonal, communication, problem-solving, technology, decision making, and management skills, in addition to technical competence. DuPre and Williams (2011) examined undergraduates' perceptions of employer expectations and found that the employer preference is the desire for relevant work experience. They pointed out that placing students in a field-related work experiences is a high institutional goal.

Hodges and Burchell (2003) surveyed New Zealand employers' views of how well business graduates are prepared for the workplace. They found that employers place a great emphasis on graduates' soft skills, and their ability to deal empathetically and effectively with job demand. They provided evidence that employers believe graduates have unrealistic expectations of life in the business world, and are generally deficient in interpersonal skills. Hodges and Burchell recommended that cooperative education programs can help students to understand that the workplace is a place where they must take responsibility for identifying their own learning needs and then do something about it.

Andrews and Higson (2008) explored employer perspectives of business graduate employability in four European countries (UK, Austria, Slovenia and Romania). They found that there are notable similarities in employer perspectives of what may be termed 'core components' of business graduate employability. The core components include the value of hard business-related knowledge and skills, the importance of soft business-related skills and competencies, and the need for prior work-experience.

Singh and Singh (2008) investigated employers perception about employability skills needed in Malaysian job market. They found employers prefer to hire graduates from public universities. They observed that the Malay employer rated graduates with information Communication Technology (ICT) and communication skills more favorably than other groups. They also found the younger the employer the more favorable was his/her 
perception of graduates' employability skills. According to Rasul and Puvanasvaran (2009), the employer in the manufacturing industry in Malaysia view basic skills, thinking skills, sources skills, resources skills, system and technology skills and personal qualities as being the most important skills. Similarly, Zaharim et al. (2010) indicated that personal attributes, personal skills, and knowledge are important to Malaysian employers. Ismail et al. (2011) compared graduates from different institutes and observed that University Kebangsaan Malaysia (UKM) graduates are better in leadership and Malay language proficiency, whereas other local graduates are better in interpersonal and communication skill, decision making and problem solving skill and team player. Singh and Choo (2012) demonstrated that Malaysian manufacturing industry employers perceive that the graduate employees' English language proficiency skills are still below their expectations. They recommend emphasis on the importance of English to be in line with globalization and current workplace demands. Ting and Ying (2012) revealed that practitioners and academicians have similar perception on the importance of business graduates' competencies regarding written skills, oral skills, research skills, knowledge-acquiring skills, honesty, diligence, resourcefulness, value-improving, teamwork ability, innovative skills and computer skills. MdSaad et al. (2013) found that problem-solving, tool handling competency and presentation skills are highly featured amongst the skills demanded of graduates by employers. MdSaad et al. added that an employee, who possesses the ability to think critically, act logically, and evaluate situations to make decisions and solve problems, is a valuable asset to the organization. Rasul et al. (2013) pointed out that employers place great importance to interpersonal skills, thinking skills and personal qualities that students need to emphasize to be employed in the manufacturing sector. They also provided evidence that employers stress that every position in any size of industry requires some kind of teamwork.

Weligamage and Siengthai (2003) looked into employers' needs from university graduates in Sir Lanka. They found university graduates' possessions of key skills sought by employers are lacking. They also noticed that universities do not generate the required labor skills for the society and undergraduates' lack of knowledge about the reality of the labor market situation. Weligamage and Siengthai (2003) made the point that skill mismatch leads to more number of unemployable graduates in the economy.

Navehebrahim (2009) considered the higher education quality from the perspective of university graduates in Iran. He found there is a high degree of satisfaction with the curriculum but a relative satisfaction with the educational experience. He also observed low level of satisfaction with the acquisition of research abilities and research experience. He concluded that there is a need to modify the curriculum to have a more practical orientation to meet student needs as well as benefiting from employers advice.

Branine (2008) assessed changes in the methods of graduate recruitment and selection that have been used by UK. He found that all employers, regardless of the organization size or activity type, tend to use more sophisticated and cost-effective methods of recruitment and selection than before. Branine provided evidence that the process of graduate recruitment and selection in the UK has become more person-related than job-oriented because many employers are more interested in the attitudes, personality and transferable skills of applicants than the type or level of qualification acquired. O'Regan (2010) observed that universities have employability strategies to tackle skills deficits and to ensure better link between universities, employers and business. However, young people approach their careers and the labor market in different ways. O'Regan concluded that graduate success is not only measured in graduate destinations but in how well graduates are prepared to survive in the world of competitive labor market. Saunders and Zuzel (2010) added that employers ranked personal qualities very highly. They also found that employers ranked a number of the personal attributes and core skills more highly than technical and subject-specific skills. Saunders and Zuzel argue that employers do not value technical competence as highly as certain personal skills.

Raza and Naqvi (2011) studied employers' perceptions about the quality of Pakistani university graduates in terms of their development skills namely intellectual, personal, professional, and social. They found that employers are not fully satisfied with the quality of Pakistani university graduates in all the four areas of development skills. They also found that Personal development skills are strong, whereas social development skills are at the lowest count.

In Nigeria, Anho (2011) conducted a comparative evaluation of how the public and private sector employers perceive the employability of universities' graduates. He found that there are significant differences in the perception and rating of the quality and employability of the graduates by the public and private sectors. $\mathrm{He}$ observed that whilst the private sector employers consider graduates of Nigeria Universities as high quality; the public sector employers rated the graduates as low quality. Anho concluded that curriculum should be reviewed to suit the country's various industries' needs. Imeokparia and Kennedy (2012) noticed that thinking skills of business graduates are not as high as that of personal quality skill and concluded that the current level of skills 
possessed by Business graduates is satisfactory to secure placement in the work world.

Blom and Saeki (2011) searched employability and skill set of newly Graduated Engineers in India. They found that employers hiring fresh engineering graduates are somewhat satisfied with the quality of the new hires. They found that employers perceive soft skills such as core employability skills and communication skills to be very important. They suggest that engineering education institutions should seek to improve the skill set of graduates; recognize the importance of soft skills and interact more with employers to understand the particular demand for skills in that region and sector. Padmini (2012) confirmed that soft skills are identified to be the most critical skills for technical and management graduates. Padmini observed that lack of people skills and communication skills is quite obvious.

Klibi and Oussii (2013) analyzed students' perceptions about the skills set required, and tried to bring them closer to employers' expectations in the Tunisian case. They found that employers emphasized the need for graduates to develop generic skills related to ethical awareness, communication, critical analysis and teamwork. They found that Tunisian employers are expecting graduates to be far more 'job ready' than is actually the case which results in gaps between students' perceptions and employers' expectations. They concluded that universities have to develop coherent policies and frameworks to promote cognitive intelligence, social, vocational and personal development.

Naidoo et al. (2011) investigated a sample of Australian accounting graduates and found they did not demonstrate high levels of skills such as team skills and oral communication and provided evidence that an expectation-performance gap exists despite efforts to articulate the attributes required of accounting graduates. According to Kavanagh and Drennan (2008), employers expected graduates entering the profession to possess top three skills: analytical/problem solving skills, a level of business awareness or real life experience and basic accounting skills. They noticed that employers expect oral communication skills, ethical awareness and professional skills, teamwork, written communication and an understanding of the interdisciplinary nature of business. They found that employers rank oral communication as being highly valued and suggested a need of accounting educators to adapt accounting curriculum by incorporating work integrated learning into accounting programs.

Balaceanu et al. (2013) attested Romanian employers degree of satisfaction of graduates professional skills. They found that the majority of employers consider that their employees' knowledge is sufficient and corresponds to the company's needs. They also found the main graduates weakness is lack of practical experience. They concluded that employers recommended adjusting the curricula, including a reasonable number of practical training hours and signing partnerships with the business environment in order to create favorable premises for the student.

On the other hand, few studies were undertaken in GCC region to investigate employers' perception about the quality of university's graduates (see for example, United Arab Emirates (UAE): El-Sakran and Awad, 2012). El-Sakran and Awad (2012) conducted semi-structured interviews to find out employability skills demanded by UAE engineering companies' employers from new recruits. They found there are deficiencies in fresh engineering graduates' oral and written communication skills and some other personal attributes. EL-Sakran and Awad suggested that colleges of engineering in non-English speaking countries should recognize the fact that English fluency is a necessary condition for success in a global economy. Thus, a strong emphasis should be placed on developing excellence in communication skills, both written and oral, an important issue that should be accorded extra focus in non-English speaking countries.

Drawing from the above literature, the current study is set out to test the following hypotheses:

Hypothesis 1: Employers assign high levels of importance to knowledge possessed by business graduates in Kuwait.

Hypothesis 2: Employers assign high levels of importance to soft skills possessed by business graduates in Kuwait.

Hypothesis 3: Employers attach high levels of importance to personal abilities possessed by business graduates in Kuwait.

Hypothesis 4: Employers attach high levels of importance to the ability of business graduates in Kuwait to work within a group.

Hypothesis 5: The levels of importance employers attach to employability factors are not affected by their background characteristics. 


\section{Data Collection and Study Methodology}

During May 2014,400 questionnaires were distributed to employers represented by managers of banks and companies. Unlike previous studies; the current study classifies employer's requirements for business graduates' employability into four main categories: Knowledge, soft skills, personal abilities and ability to work within a group. Hence, the questionnaire contained four sections to reflect these four categories. The participants were asked to specify the level of importance they assign to graduates knowledge, skills and personal abilities and ability to work within a group listed in the questionnaire by using 1- 5 likert scale, where 1 denotes not important at all and 5 denotes very important.

Out of the 200 distributed questionnaires, 111 retuned completed resulting in 56\% usable response rate. To assess reliability of the completed questionnaires, Cronbach's Alpha coefficient of reliability was undertaken to assess internal consistency of the participant's answers and appeared to be 0.833 . This suggests that the items covered in the questionnaire have a relatively high internal consistency. A reliability coefficient of 0.70 or more is considered acceptable in social science research.

Descriptive statistics will be used to identify the most important factors that employers expect a business graduate to possess. To identify whether employers different background characteristics affect the importance they assign to employability factors possessed by business graduates in Kuwait, the Kruskal-Wallis coefficient will be performed.

\section{Results of the Analysis}

\subsection{Participants' Background}

The first part of the questionnaire seek background information about the participants including: nationality, gender, age, academic qualifications, place of the last academic qualifications and years of experience. A summary of the participants' background is presented in table 1 .

Table 1. Summary of the participants' background

\begin{tabular}{|c|c|c|c|c|}
\hline & & Frequency & Percent & $\begin{array}{l}\text { Cumulative } \\
\text { Percent }\end{array}$ \\
\hline & Kuwaiti & 52 & 46.8 & 46.8 \\
\hline \multirow[t]{3}{*}{ Nationality } & Non-Kuwaiti & 59 & 53.2 & 100.0 \\
\hline & Total & 111 & 100.0 & \\
\hline & Male & 57 & 51.4 & 51.4 \\
\hline \multirow[t]{2}{*}{ Gender } & Female & 54 & 48.6 & 100.0 \\
\hline & Total & 111 & 100.0 & \\
\hline \multirow[t]{4}{*}{ Last Academic Qualifications } & University degree & 79 & 71.2 & 71.2 \\
\hline & Masters & 29 & 26.1 & 97.3 \\
\hline & Doctorate & 3 & 2.7 & 100.0 \\
\hline & Total & 111 & 100.0 & \\
\hline \multirow[t]{4}{*}{ Age } & From 25- 35 & 45 & 40.5 & 40.5 \\
\hline & From $36-50$ & 57 & 51.4 & 91.9 \\
\hline & More than 50 & 9 & 8.1 & 100.0 \\
\hline & Total & 111 & 100.0 & \\
\hline \multirow{5}{*}{$\begin{array}{l}\text { Place of the last academic } \\
\text { qualifications }\end{array}$} & Kuwait & 41 & 36.9 & 36.9 \\
\hline & Arab Country & 38 & 34.2 & 71.2 \\
\hline & UK & 16 & 14.4 & 85.6 \\
\hline & USA & 12 & 10.8 & 96.4 \\
\hline & Others & 4 & 3.6 & 100.0 \\
\hline \multirow[t]{2}{*}{ Years of Experience } & Less than 3 years & 35 & 31.5 & 31.5 \\
\hline & from 3-10 years & 38 & 34.2 & 65.8 \\
\hline
\end{tabular}




\begin{tabular}{llll}
\hline from 10- 15 years & 34 & 30.6 & 96.4 \\
More than 15 years & 4 & 3.6 & 100.0 \\
Total & 111 & 100.0 & \\
\hline
\end{tabular}

It is evident from the table that the participants' are Kuwaitis and non-Kuwaitis and they represent both genders almost equally. The participants also cover different age groups and have a range of work experience. A significant proportion of the participants hold high academic degrees. What attracts attention in table (1) is a significant proportion of the participants who took part in the survey are educated in UK and USA.Almost one quarter of the participants completed their last academic qualifications in UK and USA. The range of differences in the participants' background is expected to give credibility to the outcome of the analysis.

\subsection{Knowledge Factors}

A number of knowledge variables expected to be possessed by business graduates were included in the questionnaire and the participants were asked to express the level of importance they attach to each of these variables. The results of their answers are summarized in table 2 .

Table 2. The importance participants' attach to business graduates knowledge in their employability decision

\begin{tabular}{|c|c|c|c|c|c|c|c|}
\hline Knowledge Factors & $\mathbf{N}$ & Mean & Median & $\begin{array}{l}\text { Std. } \\
\text { Deviation }\end{array}$ & Minimum & Maximum & $\begin{array}{l}\text { Rank } \\
\text { based on } \\
\text { the mean }\end{array}$ \\
\hline Resourcefulness & 111 & 3.96 & 4.00 & 0.80 & 2.00 & 5.00 & 1 \\
\hline Global awareness & 111 & 3.16 & 3.00 & 0.97 & 2.00 & 5.00 & 6 \\
\hline Self-understanding & 111 & 3.47 & 3.00 & 0.83 & 2.00 & 5.00 & 4 \\
\hline Understanding workplace & 111 & 3.46 & 3.00 & 0.67 & 2.00 & 5.00 & 5 \\
\hline Value improving & 111 & 3.88 & 4.00 & 0.75 & 2.00 & 5.00 & 2 \\
\hline Self-quality control & 111 & 3.63 & 3.00 & 0.75 & 2.00 & 5.00 & 3 \\
\hline All & 111 & 3.59 & 3.00 & 0.80 & 2.00 & 5.00 & \\
\hline
\end{tabular}

It can be noticed from table 2 that the participants attach high levels of importance to all knowledge factors listed in the questionnaire as reflected by the mean and the median of each of these factors. The relatively low standard deviations appeared on the table indicate that there was low variations in the level of importance that the participants attach to each of the knowledge factors. The table disclosed that employers took part in the survey attach the highest levels of importance to factors such as resourcefulness, value improving and self- quality control. On the other hand, the participants assign the lowest levels of importance to global awareness and understanding the work place. This result reflects the nature of the Kuwaiti businesses run by the participants in the survey. Employers covered in the current survey are mainly from the services sector that is repetitive and reflects its environment and does not require global awareness. For example, the banking and telecommunications sectors in Kuwait are different than those in the West. This is due to the size of the market. The size of the market of Kuwait is very small and many banks and companies are competing within this market. This makes the relationship between business operating in the services sector and its customers more interment than in the west where they have large markets and many customers. The repetitive nature of operation performed by the services firms together with and the small size of these firms and the Kuwaiti market make it easy to understand the work place. Hence, understanding the work place does not seem to be an important factor that determines business graduates employability in Kuwait.

The Kruskal Wallis Coefficient reported in table 3 showed consensus among the participants regardless of their background about the importance they attach the knowledge factors of the business graduates in Kuwait except for the participants experience and the resourcefulness factor. This might be explained on the grounds that highly experienced employers demand more knowledge from employees, bearing in mind that more than one third of the participants have more than 10 years of work experience. 
Table 3. Kruskal Wallis-Knowledge factors

\begin{tabular}{|c|c|c|c|c|c|c|c|c|c|c|}
\hline \multirow[b]{2}{*}{ Knowledge Factors } & \multicolumn{2}{|c|}{ Nationality } & \multicolumn{2}{|c|}{ Gender } & \multicolumn{2}{|l|}{ Age } & \multicolumn{2}{|c|}{$\begin{array}{l}\text { Place of last } \\
\text { Academic Degree }\end{array}$} & \multicolumn{2}{|c|}{ Experience } \\
\hline & $x^{2}$ & $\begin{array}{l}\text { Sig. } \\
\text { (2-tailed) }\end{array}$ & $x^{2}$ & $\begin{array}{l}\text { Sig. } \\
\text { (2-tailed) }\end{array}$ & $x^{2}$ & $\begin{array}{l}\text { Sig. } \\
\text { (2-tailed) }\end{array}$ & $x^{2}$ & $\begin{array}{l}\text { Sig. } \\
\text { (2-tailed) }\end{array}$ & $x^{2}$ & $\begin{array}{l}\text { Sig. } \\
\text { (2-tailed) }\end{array}$ \\
\hline Resourcefulness & 0.531 & 0.466 & 0.427 & 9.784 & 0.008 & 9.784 & 9.851 & 0.043 & 11.612 & 0.009 \\
\hline Global awareness & 0.164 & 0.686 & 0.005 & 0.366 & 0.833 & 0.366 & 6.078 & 0.193 & 3.671 & 0.299 \\
\hline self-understanding & 0.014 & 0.907 & 4.205 & 2.601 & 0.272 & 2.601 & 4.661 & 0.324 & 7.99 & 0.046 \\
\hline Understanding workplace & 7.044 & 0.008 & 6.506 & 3.145 & 0.207 & 3.145 & 3.974 & 0.41 & 7.17 & 0.067 \\
\hline Value improving & 0.928 & 0.335 & 0.384 & 3.127 & 0.209 & 3.127 & 3.801 & 0.434 & 2.979 & 0.395 \\
\hline Self-quality control & 0.367 & 0.544 & 3.584 & 7.115 & 0.029 & 7.115 & 2.96 & 0.565 & 3.666 & 0.3 \\
\hline
\end{tabular}

\subsection{Soft Skills Factors}

The questionnaire contained a number of soft skills and the participants were asked to indicate the importance they attach to each of these factors when recruiting business graduates in Kuwait. The results of their answers are reported in table 4 .

Table 4. The importance participants' attach to business graduates soft skills in their employability decision

\begin{tabular}{llllllll}
\hline & N & Mean & Median & $\begin{array}{l}\text { Std. } \\
\text { Deviation }\end{array}$ & Minimum & $\begin{array}{l}\text { Maximum } \\
\text { based } \\
\text { the mean }\end{array}$ \\
\hline Oral communication skills & 111 & 3.57 & 4.00 & 0.71 & 2.00 & 5.00 & 7 \\
Writing communication skills & 111 & 3.59 & 4.00 & 0.69 & 2.00 & 5.00 & 6 \\
Presentation skills & 111 & 3.69 & 4.00 & 0.89 & 2.00 & 5.00 & 5 \\
Research skills & 111 & 3.74 & 4.00 & 0.76 & 2.00 & 5.00 & 4 \\
Numerical skills & 111 & 3.86 & 4.00 & 0.80 & 2.00 & 5.00 & 1 \\
Computing skills & 111 & 3.86 & 4.00 & 0.79 & 2.00 & 5.00 & 1 \\
Evaluation skills & 111 & 3.46 & 4.00 & 0.98 & 2.00 & 5.00 & 9 \\
Learning skills & 111 & 3.53 & 4.00 & 0.83 & 2.00 & 5.00 & 8 \\
Analytical skills & 111 & 3.77 & 4.00 & 0.83 & 2.00 & 5.00 & 3 \\
All & 111 & 3.67 & 4.00 & 0.81 & 2.00 & 5.00 & \\
\hline
\end{tabular}

It can be seen from table 4 that the participants attach a relatively high level of importance to all soft skills listed in the questionnaire as reflected by the reported means and the medians. The relatively low levels of standard deviations appeared on Tale 4 point to consensus among the participants about the level of importance they attach each of the soft factors contained in the questionnaire. The table also revealed that participants attach the highest levels of importance to factors such as numerical, computing and analytical skills. The lowest levels of importance appeared to be attached to soft skills such as evaluation, learning, oral and writing skills. Once again, the results reflect the nature of the businesses run by the participants. Services businesses require a certain level of numerical, computing and analytical skills, bearing in mind that the participants are mainly employers from the banking and telecommunications sectors. The repetitive nature of work of these sectors requires a limited number of employees to possess learning, writing and presentation skills.

The Kruskal Wallis coefficient presented in table 5 showed full consensus among the participants about the level of importance they attach to each of the listed soft factors regardless of their gender. The table, however, pointed to a number of differences in the level of importance the participants attach to each of the listed soft factors due to differences in the participants age, place of the last academic degree and experience. The results of the Kruskal Wallis are explained on the grounds participants with difference age and experience are more likely to 
have to different expectations about business graduates. Participants who completed their studies in Western universities are expected to attach high importance to soft skills different than graduates from Arab or local universities.

Table 5. Kruskal Wallis-soft skills

\begin{tabular}{|c|c|c|c|c|c|c|c|c|c|c|}
\hline \multirow[b]{2}{*}{ Soft Skills } & \multicolumn{2}{|c|}{ Nationality } & \multicolumn{2}{|c|}{ Gender } & \multicolumn{2}{|l|}{ Age } & \multicolumn{2}{|c|}{$\begin{array}{l}\text { Place of last } \\
\text { academic degree }\end{array}$} & \multicolumn{2}{|c|}{ Experience } \\
\hline & $x^{2}$ & $\begin{array}{l}\text { Sig. } \\
\text { (2-tailed) }\end{array}$ & $x^{2}$ & $\begin{array}{l}\text { Sig. } \\
\text { (2-tailed) }\end{array}$ & $x^{2}$ & $\begin{array}{l}\text { Sig. } \\
\text { (2-tailed) }\end{array}$ & $x^{2}$ & $\begin{array}{l}\text { Sig. } \\
\text { (2-tailed) }\end{array}$ & $x^{2}$ & $\begin{array}{l}\text { Sig. } \\
\text { (2-tailed) }\end{array}$ \\
\hline Oral communication skills & 7.142 & 0.008 & 0.495 & 0.481 & 4.088 & 0.129 & 20.3 & $\mathbf{0}$ & 23.669 & 0 \\
\hline $\begin{array}{l}\text { Writing communication } \\
\text { skills }\end{array}$ & 6.653 & 0.01 & 0.786 & 0.375 & 4.214 & 0.122 & 21.067 & $\mathbf{0}$ & 18.391 & 0 \\
\hline Presentation skills & 3.202 & 0.074 & 1.709 & 0.191 & 4.754 & 0.093 & 10.194 & 0.037 & 12.013 & 0.007 \\
\hline Research skills & 0.128 & 0.72 & 2.498 & 0.114 & 6.98 & 0.031 & 7.095 & 0.131 & 6.456 & 0.091 \\
\hline Numerical skills & 3.751 & 0.053 & 0.298 & 0.585 & 8.985 & 0.011 & 12.03 & 0.017 & 12.114 & 0.007 \\
\hline Computing skills & 2.676 & 0.102 & 0.39 & 0.532 & 4.665 & 0.097 & 15.404 & 0.004 & 21.442 & 0 \\
\hline Evaluation skills & 7.801 & 0.005 & 0.261 & 0.609 & 2.312 & 0.315 & 0.866 & 0.929 & 23.705 & 0 \\
\hline Learning skills & 3.706 & 0.054 & 1.497 & 0.221 & 6.934 & 0.031 & 11.548 & 0.021 & 18.078 & 0 \\
\hline Analytical skills & 0.82 & 0.365 & 1.45 & 0.228 & 7.126 & 0.028 & 4.506 & 0.342 & 9.639 & 0.022 \\
\hline
\end{tabular}

\subsection{Personal Abilities}

The questionnaire contained a number of personal abilities factors that employers expect business graduates to possess them to ensure employability. The participants were asked to express the level of importance they attach to each of these factors. The outcome of their answers is presented in table 6 .

Table 6. The importance participants' attach to business graduates personal abilities in their employability decision

\begin{tabular}{|c|c|c|c|c|c|c|c|}
\hline & $\mathbf{N}$ & Mean & Median & $\begin{array}{l}\text { Std. } \\
\text { Deviation }\end{array}$ & Minimum & Maximum & $\begin{array}{l}\text { Rank } \\
\text { based on } \\
\text { the mean }\end{array}$ \\
\hline Dependability & 111 & 3.62 & 4.00 & 0.84 & 2.00 & 5.00 & 5 \\
\hline Honesty & 111 & 3.48 & 4.00 & 0.80 & 2.00 & 5.00 & 8 \\
\hline Diligence & 111 & 3.51 & 4.00 & 0.92 & 2.00 & 5.00 & 7 \\
\hline Risk assessment & 111 & 3.20 & 4.00 & 1.05 & 1.00 & 5.00 & 12 \\
\hline Risk management & 111 & 3.18 & 3.00 & 0.94 & 1.00 & 4.00 & 13 \\
\hline Time management & 111 & 3.35 & 3.00 & 0.77 & 2.00 & 5.00 & 10 \\
\hline Decision making & 111 & 3.29 & 3.00 & 0.92 & 1.00 & 5.00 & 11 \\
\hline Career Planning & 111 & 3.41 & 4.00 & 0.81 & 2.00 & 5.00 & 9 \\
\hline Initiative & 111 & 3.87 & 4.00 & 0.83 & 2.00 & 5.00 & 2 \\
\hline Flexibility & 111 & 3.93 & 4.00 & 0.87 & 2.00 & 5.00 & 1 \\
\hline Energetic & 111 & 3.62 & 4.00 & 0.78 & 2.00 & 5.00 & 5 \\
\hline Passionate & 111 & 3.63 & 4.00 & 0.83 & 2.00 & 5.00 & 4 \\
\hline Self confidence & 111 & 3.77 & 4.00 & 0.79 & 3.00 & 5.00 & 3 \\
\hline All & 111 & 3.50 & 4.00 & 0.86 & 1.00 & 5.00 & \\
\hline
\end{tabular}

Table 6 demonstrates that the participants attach relatively high levels of importance to all personal abilities factors covered in the questionnaire as reflected by the reported means and medians. The relatively low reported standard deviations appeared in table 6 indicate that there is a certain degree of consensus among the participants on the level of importance they attach to each of these factors. However, the participants seem to attach the 
highest levels of importance to factors such as flexibility, initiative, self-confidence, passionate, energetic and dependability. Yet, factors such as risk management, risk assessment and decision making received the lowest levels of importance. Once again, the results reflect the nature of firms covered in the survey which requires a certain degree of flexibility and initiative. The employee cannot be flexible and initiative unless he/ she is self-confidence and passionate about his/ her work.

The Kruskal Wallis coefficient reported in table 7 showed that participants' nationality and gender have no effect on the importance they attach to business graduates personal abilities. However, other background characteristics of the participants such as age, place of last academic qualifications and experience affect the importance they attach to business graduates personal abilities. In other words the level of importance attach by experienced employers is different than the level attached by less experienced employers. The same thing is applied to the employers' place of the last academic experience. The level of importance attached by employers graduated from Westerns universities is different than the levels of importance attached by employers' graduates from Arab and local universities academic experience. The level of importance attached by employers graduated from Westerns universities is different than the levels of importance attached by employers' graduates from Arab and local universities.

Table 7. Kruskal Wallis- personal abilities

\begin{tabular}{|c|c|c|c|c|c|c|c|c|c|c|}
\hline & \multicolumn{2}{|c|}{ Nationality } & \multicolumn{2}{|l|}{ Gender } & \multicolumn{2}{|l|}{ Age } & \multicolumn{2}{|c|}{$\begin{array}{l}\text { Place of last Academic } \\
\text { Degree }\end{array}$} & \multicolumn{2}{|c|}{ Experience } \\
\hline & $x^{2}$ & $\begin{array}{l}\text { Sig. } \\
\text { (2-tailed) }\end{array}$ & $x^{2}$ & $\begin{array}{l}\text { Sig. } \\
\text { (2-tailed) }\end{array}$ & $x^{2}$ & $\begin{array}{l}\text { Sig. } \\
\text { (2-tailed) }\end{array}$ & $x^{2}$ & $\begin{array}{l}\text { Sig. } \\
\text { (2-tailed) }\end{array}$ & $x^{2}$ & $\begin{array}{l}\text { Sig. } \\
\text { (2-tailed) }\end{array}$ \\
\hline \multicolumn{11}{|l|}{ Personal Abilities } \\
\hline Dependability & 0.105 & 0.746 & 0.026 & 0.873 & 3.299 & 0.192 & 3.268 & 0.514 & 21.602 & 0 \\
\hline Honesty & 0.064 & 0.8 & 1.133 & 0.287 & 3.06 & 0.217 & 5.447 & 0.244 & 1.436 & 0.697 \\
\hline Diligence & 0.148 & 0.7 & 0.576 & 0.448 & 0.88 & 0.644 & 2.808 & 0.59 & 7.006 & 0.072 \\
\hline Risk assessment & 0.275 & 0.6 & 0.896 & 0.344 & 9.212 & 0.01 & 15.411 & 0.004 & 12.057 & 0.007 \\
\hline Risk management & 0.884 & 0.347 & 0.079 & 0.779 & 8.573 & 0.014 & 34.421 & 0 & 7.942 & 0.047 \\
\hline Time management & 0.007 & 0.931 & 3.318 & 0.069 & 9.319 & 0.009 & 10.061 & 0.039 & 3.12 & 0.374 \\
\hline Decision making & 5.03 & 0.025 & 0.732 & 0.392 & 2.584 & 0.275 & 16.156 & 0.003 & 16.966 & 0.001 \\
\hline Career Planning & 0.323 & 0.57 & 0.301 & 0.583 & 0.951 & 0.622 & 14.548 & 0.006 & 9.745 & 0.021 \\
\hline Initiative & 1.585 & 0.208 & 0.067 & 0.795 & 5.526 & 0.063 & 8.729 & 0.068 & 3.355 & 0.34 \\
\hline Flexibility & 1.106 & 0.293 & 2.059 & 0.151 & 26.179 & 0 & 14.297 & 0.006 & 2.804 & 0.423 \\
\hline Energetic & 0.147 & 0.702 & 4.033 & 0.045 & 7.033 & 0.03 & 2.957 & 0.565 & 12.09 & 0.007 \\
\hline Passionate & 0.544 & 0.461 & 0.733 & 0.392 & 24.631 & 0 & 4.091 & 0.394 & 2.19 & 0.534 \\
\hline Self confidence & 1.304 & 0.254 & 1.899 & 0.168 & 12.582 & 0.002 & 6.668 & 0.155 & 12.602 & 0.006 \\
\hline
\end{tabular}

\subsection{Working Within Groups}

The questionnaire contained a number of factors relating working within groups and the participants were asked to express the level of importance they assign to each of these factors. The results of their answers are summarized in table 8 . 
Table 8 . The importance participants' attach to business graduates ability to work within groups

\begin{tabular}{|c|c|c|c|c|c|c|c|}
\hline & $\mathbf{N}$ & Mean & Median & $\begin{array}{l}\text { Std. } \\
\text { Deviation }\end{array}$ & Minimum & Maximum & $\begin{array}{l}\text { Rank } \\
\text { based on } \\
\text { the mean }\end{array}$ \\
\hline Adoptability & 134 & 3.76 & 4.00 & 0.87 & 2.00 & 5.00 & 2 \\
\hline Leadership skills & 134 & 3.48 & 3.00 & 0.74 & 2.00 & 5.00 & 4 \\
\hline Teamwork ability & 134 & 3.67 & 4.00 & 0.85 & 1.00 & 5.00 & 3 \\
\hline Working with diversity & 134 & 3.33 & 4.00 & 0.98 & 2.00 & 5.00 & 5 \\
\hline Work ethics & 134 & 4.11 & 4.00 & 0.80 & 3.00 & 5.00 & 1 \\
\hline All & 134 & 3.67 & 4.00 & 0.85 & 1.00 & 5.00 & \\
\hline
\end{tabular}

The participants expressed relatively high levels of importance to all working within groups factors contained in the questionnaire. However, the highest level of agreement was assigned to work ethics, adoptability and team work abilities. Yet, leadership skills and working with diversity received the lowest levels of importance. This result again reflects the nature of the firms covered in the survey and the peculiarity of the Kuwaiti market. The activities of the services firms covered in the current study are repetitive and not diversified. Needless to say businesses in Kuwait are run by a number of families. Hence, leadership posts are mainly restricted to family members, their relatives and others trusted by them. Hence, leadership skills are not viewed as being an important factor in recruiting business graduates in Kuwait.

To determine whether participants' background characteristics impact the level of importance they attach to working within groups factors, Kruskal Wallis coefficient was undertaken and reported in table 9.

Table 9: Kruskal Wallis- Working within groups

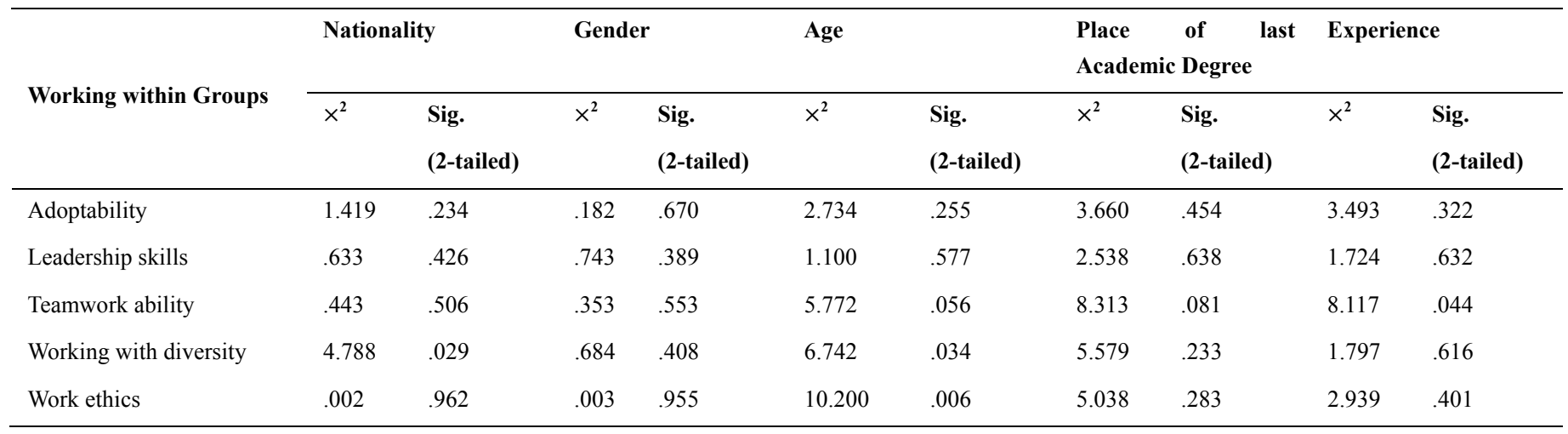

It can be observed from the table that there is insignificant differences between the participants about the level of importance they attached to almost all factors regardless of their background characteristics except for the work ethics factor and participants age. It seems that the importance attached by young generation to work ethics factors is significantly different than that attached by old generation.

Factoring the four categories used by employers to determine business graduates employability in Kuwait by taking the mean of all variables that formed each factor showed that the participants attach highest importance to knowledge, soft skills and graduates ability to work within groups. The participants showed that they attach low levels of importance to the business graduates personal abilities when they consider them for jobs opportunities. The participants attach the highest importance to the following factors in sequence: work ethics, resourcefulness, value improving, Initiative, computing skills, numerical skills, analytical skills, self-confidence and adoptability.

\section{Conclusion}

Different studies have been undertaken to determine factors considered by employers when recruiting business graduates. These factors were classified into four categories and included in a questionnaire. Kuwait employers were asked to express the level of importance they attach to each of these factors when recruiting business graduates. The results of the analyses of their answers revealed that they attach high importance to the graduates' 
knowledge, soft skills and their ability to work within groups. They, however, attach lower importance to the business graduates' personal abilities. When recruiting business graduates in Kuwait, employers attach the highest importance to the following factors in sequence: work ethics, resourcefulness, value improving, Initiative, computing skills, numerical skills, analytical skills, self-confidence and adoptability. These results accept hypotheses 1, 2 and 4 and rejects hypothesis 3 .

The Kruskal Wallis coefficient showed that the level of importance attached to various factors considered by employers when recruiting business graduates vary according to employers' background characteristics; hence, rejecting hypothesis 5 .

It is, therefore, fair to conclude that employability factors are determined by the background characteristics of the employer, nature of the job, ownership of the firm (whether owned by families, publicly, government), and the size of the market. In case of Kuwait as well as other Arab countries, cultural and social factors have substantial effect on the employability.

\section{References}

Al-Alawneh, M., Meqdadi, R., Al-Refai, A., Khdair, R., \& Malkawi, A. (2010). Examining the effect of college type, study level, and gender of students on their use of teamwork skills as they perceived at Yarmouk University of Jordan. Canadian Social Science, 7(6), 48-57.

Alkhazim, M. (2003). Higher education in Saudi Arabia: Challenges, solutions, and opportunities missed'. Higher Education Policy, 16(4), 479-486. http://dx.doi.org/10.1057/palgrave.hep.8300035

Alston, A., Cromartie, W., English, Ch., \& Wakefield, D. (2009). Employer perceptions of graduates of the United States land Grant University system's workforce preparation. Online Journal of Workforce Education and Development, 3(4), 1-11.

Andrews, J., \& Higson, H. (2008). Graduate employability, 'soft skills' versus 'hard' business knowledge: A European study. Higher Education in Europe, 33(4), 411-422. http://dx.doi.org/10.1080/03797720802522627

Anho, J. (2011). An evaluation of the quality and employability of graduates of Nigeria Universities. African Journal of Social Sciences, 1(1), 179-185.

Archer, W., \& Davison, J. (2008). Graduate employability, What do employers think and want? London: the Council for Industry and Higher Education (CIHE).

Balaceanu, C., Zaharia, V., Tilea, D., Predonu, M., Apostol, D., \& Dogaru, M. (2013). Questionnaire on analyzing the degree of satisfaction regarding the professional skills of the graduates as perceived from the employers' perspective. International Journal of Academic Research in Economics and Management Sciences, 2(1), 261-278.

Blom, A., \& Saeki, H. (2011). Employability and skill set of newly graduated engineers in India. Policy Research Working Paper, 5640. http://dx.doi.org/10.1596/1813-9450-5640

Borzi, G., \& Mills, T. H. (2001). Communication apprehension in upper level accounting students: An assessment of skill development. Journal of Education for Business, 76(4), 193-198. http://dx.doi.org/10.1080/08832320109601310

Branine, M. (2008). Graduate recruitment and selection in the UK: A study of the recent changes in methods and expectations. Career Development International, 13(6), 497-513.

Bui, B., \& Porter, B. (2010). The Expectation-Performance Gap in Accounting Education: An Exploratory Study. Accounting Education: An International Journal, 19(1-2), 23-50. http://dx.doi.org/10.1080/09639280902875556

Burchell, N., Hodges, D., \& Rainsbury, E. (2001). What competencies do business graduates require? Perspectives of New Zealand stakeholders. Journal of Cooperative Education, 35(2-3), 11-20.

Canny, A. (2010). What employers want and what employers do: Cumbrian employers' recruitment, assessment and provision of education/learning opportunities for their young workers. Journal of Education and Work, 17(4), 495-513. http://dx.doi.org/10.1080/1363908042000292065

Chaker, N., \& Abdullah, T. (2011). What accountancy skills are acquired at college? International Journal of Business and Social Science, 2(18), 193-199.

DuPre, C., \& Williams, K. (2011). Undergraduates' perceptions of employer expectations. Journal of Career and 
Technical Education, 26(1), 8-19.

EL-Sakran, Th., \& Awad, A. (2012). Voices from the United Arab Emirates: Engineering graduates' Labour market requisite competencies. American Journal of Engineering Education, 3(2), 105-114.

Faisal, F. (2010). Measuring perceptions of work environment among educated female public servants in Pakistan. Pakistan Economic and Social Review, 48(1), 135-165.

Goic, S. (1999). Employees' attitudes towards employee ownership and financial participation in Croatia: Experiences and cases. Journal of Business Ethics, 21(2/3), $145-155$. http://dx.doi.org/10.1023/A:1006288808755

Graham, D. (2001). Employer perception of the preparation of agricultural and extension education graduates. Journal of Southern Agricultural Education Research, 51(1), 88-101.

Hodges, D., \& Burchell, N. (2003). Business graduate competencies: Employers' views on importance and performance. Asia Pacific Journal of Cooperative Education, 4(2), 16-22.

Imeokparia, P., \& Kennedy, E. (2012). Employability of business education graduates. International Research Journals, 3(8), 645-651.

Ismail, R., Yussof, I., \& Sieng, L. (2011). Employers' perceptions on graduates in Malaysian services sector. International Business Management, 5(3), 184-193. http://dx.doi.org/10.3923/ibm.2011.184.193

Joseph, M., \& Joseph, B. (1997). Employer's perception of service quality in higher education. Journal of Marketing for Higher Education, 8(2), 1-13. http://dx.doi.org/10.1300/J050v08n02_01

Kavanagh, M., \& Drennan, L. (2008). What skills and attributes does an accounting graduate need? Evidence from student perceptions and employer expectations. Accounting \& Finance, 48(2), $279-300$. http://dx.doi.org/10.1111/j.1467-629X.2007.00245.x

Klibi, M., \& Oussii, A. (2013). Skills and attributes needed for success in accounting career: Do employers' expectations fit with students' perceptions? Evidence from Tunisia. International Journal of Business and Management, 8(8), 118-132. http://dx.doi.org/10.5539/ijbm.v8n8p118

Kumar, D., \& Jain, V. (2010). Survival skills of business management graduates: a study with reference to retail and banking. Far East Journal of Psychology and Business, 1(1), 49-77.

Lin, Z. J., Xiong, X., \& Liu, M. (2005). Knowledge base and skill development in accounting education: Evidence from China. Journal of Accounting Education, 23(3), 149-169. http://dx.doi.org/10.1016/j.jaccedu.2005.06.003

Lowden, K., Hall, S., Elliot, D., \& Lewin, J. (2011). Employers' perceptions of the employability skills of new graduates. Project Report. Edge Foundation, London, UK.

McCabe, G. (2010). Graduate attributes and employability: helping university and students prepare for the changing landscape. Interchange, Spring 2010, University of Edinburgh.

MdSaad, M., Robani, A., Jano, Z., \& Ab. Majid, I. (2013). Employers' perception on engineering, information and communication technology (ICT) students' employability skills. Global Journal of Engineering, 15(1), $42-47$.

Naidoo, J., Jackling, B., Oliver, B., \& Prokofieva, M. (2011). Identifying the employment expectation-performance gaps of early career accounting graduates. Retrieved from http://mams.rmit.edu.au/ztct5ymtl0ht.pdf

Navehebrahim, A. (2009). A study of quality from the perspective of the university graduates: A case study focusing on a small university in Iran. Contemporary Middle Eastern Issues, 2(4), $289-298$. http://dx.doi.org/10.1108/17537980911001116

O’Regan, M. (2010). Graduate transitions to employment: career motivation, identity and employability, center of career management skills, university of Reading. Retrieved from https://www.reading.ac.uk/web/FILES/ccms/Graduate_transitions_to_employment.pdf

Padmini, I. (2012). Education vs employability- the need to bridge the skills gap among the engineering and management graduates in Andhra Pradesh. International Journal of Management \& Business Studies, 2(3), 90-94.

Rasul, M., \& Puvanasvaran, A. (2009). Importance of employability skills as perceived by employers of Malaysian manufacturing industry. Journal of Human Capital Development, 2(2), $23-35$. 
http://dx.doi.org/10.5539/ass.v9n8p42

Rasul, M., Rauf, R., \& Mansor, A. (2013). Employability skills indicator as perceived by manufacturing employers.Asian Social Science, 9(8), 42-46.

Raza, S., \& Naqvi, S. (2011). Quality of Pakistani university graduates as perceived by employers: Implications for faculty development. Journal of Quality and Technology Management, 7(1), 57-72.

Raza, S., Majid, Z., \& Zia, A. (2010). Perceptions of Pakistani University students about roles of academics engaged in imparting development skills: Implications for faculty development. Bulletin of Education and Research, 32(2), 75-91.

Robinson, J., \& Garton, B. (2008). An assessment of the employability skills needed by graduates in the college of Agriculture Food and Natural Resources at the University of Missouri. Journal of Agricultural Education, 49(4), 96-105. http://dx.doi.org/10.5032/jae.2008.04096

Saunders, V., \& Zuzel, K. (2010). Evaluating employability skills: Employer and student perceptions. Bioscience Education, 15-20. Retrieved from http://www.bioscience.heacademy.ac.uk/journal/vol15/beej-15- 2.aspx

Shumilova, Y., Cai, Y., \& Pekkola, E. (2012). Employability of international graduates educated in Finnish higher education institutions, VALOA-project, Career Services, University of Helsinki. Retrieved from http://www.helsinki.fi/urapalvelut/valoasurvey/pubData/source/VALOA09.pdf

Singh, G., \& Singh, Sh. (2008). Malaysian graduates' employability skills. UNITAR E-Journal, 4(1), 15-45.

Singh, M., \& Choo, J. (2012). Manufacturing industry employers' perception of graduates' English language skills proficiency. International Journal of Applied Linguistics \& English Literature, 1(4), 114-124. http://dx.doi.org/10.7575/ijalel.v.1n.4p.114

Ting, Sh., \& Ying, Ch. (2012). Is there a gap between practitioners' and academicians' perceptions on business graduates' competencies in Malaysia. Journal of Education and Vocational Research, 3(5), 167-172.

Weligamage, S. (2009). Graduates' employability skills: Evidence from literature review, Sub Theme A-Enhancing Employability through Quality Assurance-ASAIHL. Retrieved from http://mit.kln.ac.lk/uokr/ASAIHL/SubThemeA8.pdf

Weligamage, S., \& Siengthai, S. (2003). Employer needs and graduate skills, the gap between employer expectations and job expectations of Sri Lankan University Graduates. 9th International conference on Sri Lanka Studies, Matara, Sri Lanka.

Yorke, M. (2006). Employability in higher education: what it is-what it is not. Yorke, M., No. 1 of the ESECT Learning and Employability Series. York: Higher Education Academy.

Zaharim, A., Yusoff, Y., Mohamed, A., Omar, M., Muhamad, N., \& Mustapha, R. (2010). Practical framework of employability skills for engineering graduate in Malaysia. Education Engineering (EDUCON), IEEE, 921-927.

Retrieved

from http://ieeexplore.ieee.org/stamp/stamp.jsp?tp=\&arnumber=5492478\&isnumber=5492336

\section{Copyrights}

Copyright for this article is retained by the author(s), with first publication rights granted to the journal.

This is an open-access article distributed under the terms and conditions of the Creative Commons Attribution license (http://creativecommons.org/licenses/by/3.0/). 